\title{
RAIN WATER NOT IN SEWERS BUT IN THE GARDEN - THE STUDY CASE OF THE NETHERLANDS AND POLISH EXPERIENCE
}

\author{
Agnieszka Boas Berg', Jerzy Jeznach², Maja Radziemska ${ }^{2 凶}$, Dana Adamcová3, \\ Martin Brtnický ${ }^{4}$ \\ 1 Shada BV, AM Apeldoorn, Holland \\ ${ }^{2}$ Faculty of Civil and Environmental Engineering, Warsaw University of Life Sciences - SGGW, Warsaw \\ ${ }^{3}$ Faculty of AgriSciences, Mendel University in Brno, Brno, Czech Republic \\ ${ }^{4}$ Faculty of Forestry and Wood Technology, Mendel University in Brno, Brno, Czech Republic
}

\begin{abstract}
The authors in the article presented information on the possibility of separating rainwater from municipal sewage and the possibilities of its re-use. They based their considerations on the experience of municipalities in the European Union (EU), the Dutch one in particular. The choice of the Dutch municipality of Apeldoorn was not coincidental. Apeldoorn has the highest rainfall level in all of the Netherlands. What is more, The Netherlands is one of those European countries that is highly advanced in water management. This is due to the fact that it is a small country with a very dense population, which must deal with the distribution of water resources for very populated municipalities. Moreover, $50 \%$ of this country is situated below the sea level, which causes problems with excess water in coastal provinces. The Dutch are therefore trying to manage water using all technical and legal possibilities. This article presents some solutions related to the separation of rainwater from municipal sewage and the financial possibilities offered by the municipality of Apeldoorn. The authors also shortly presented history of the use of rainwater, including Polish experiences. The authors applied research methods based on examination of documents in the municipality of Apeldoorn and interviewed municipal employees responsible for the project of separation rainwater from sewage.
\end{abstract}

Key words: rainwater, separation of rainwater, subsidies, EU grants, wadi, groundwater

\section{INTRODUCTION}

The EU is designed to meet the expectations of modern European society in terms of living standards, openness, transparency and commitment. It should also function more effectively and be able to face the global challenges of the modern world, such as climate change, problems with diminishing green areas, logging and floods (Ding, Chiabai, Silvestri \& Nunes, 2016; De Roeck, Orbie \& Delputte, 2018).

Climate change, urbanization, issues related to floods and air quality are the main problems that need to be addressed (Petrović, Bojavić \& Petrović, 2016). Appropriate rainwater management and separating it from municipal sewage may be the answer to the problem of water retention in the ecosystem (where it should be stopped). It could be also the answer to problems with accumulating rainwater in excessive amounts in undesirable places. Furthermore, the replacement of vegetated areas that provide rainwater interception and storage often results in an increase in the rate and volume of stormwater runoff (Chen, Samuelson \& Tong, 2016).

Climate change and changes introduced by man in European cities affect the biological balance between

$\bowtie_{\text {maja_radziemska@sggw.pl }}$ 
Boas Berg, A., Jeznach, J., Radziemska, M., Adamcová, D. \& Brtnický, M. (2018). Rain water not in sewers but in the garden - the study case of the Netherlands and Polish experience. Acta Sci. Pol. Architectura, 17 (1), 79-88. doi: 10.22630/ASPA.2018.17.1.8

plants, animals and people (Bellard, Bertelsmeier, Leadley, Thuiller \& Courchamp, 2012; Gardali, Seavy, DiGaudio \& Comrack, 2012; Thomas et al., 2012; Foden et al., 2013; Warren et al., 2013; Maione et al., 2016; Francés, Quevauviller, González \& Amelin, 2017). The authors chose the Netherlands deliberately because it is a country that copes with the management of land and seawaters as well as rainwater exceptionally well.

The Netherlands belongs to the rich Benelux countries, but also to one of the most densely populated countries in the world. The area of the Netherlands is $41,543 \mathrm{~km}^{2}$ and is inhabited by $17,116,281$ (estimate 2017) people. Population density is 413 people $/ \mathrm{km}^{2}$. With such high population density rate, politicians, environmentalists and the public must come to an agreement in order to maintain the balance in the natural environment. In the Dutch municipalities, dialogue, solving problems and agreeing on different positions are important. The authorities of the Dutch municipality appoint, from among representatives of local government, people whose task is to ensure that arrangements regarding environmental protection or flood protection are being fulfilled. Caring for the natural environment, segregation of waste instead of storing it, subsidizing the separation of rainwater from municipal sewage is possible due to appropriate financial and administrative-legal instruments.

Rainwater harvesting includes any type of catchment (jars, pots and tanks as well as engineered techniques), and is considered the oldest water supply technology de- veloped by man worldwide, both in rural and in urban areas (Stahn \& Tomini, 2017). However, the literature focuses mainly on the technical aspects, engineering and agronomy, despite the fact that it is mandatory to stresses the importance of socioeconomic considerations.

\section{MATERIALS AND METHODS}

In the municipality of Apeldoorn (as in most municipalities in the EU) the representative of the population are municipal authorities, whose purpose and task is to maintain the natural environment's balance between and the needs of residents of the municipality and preventing the negative effects of urbanization. Municipal authorities strive to raise public awareness of issues related to environmental protection and proper use of water resources. Rainwater, in many cases, is still not being used properly, whereas the municipality aims to make local people aware of the possibilities of its use.

The municipality has launched a special plan financing investment in private estates. These investments involve modifying rainwater runoffs from roofs and paved areas in such a way that the water can be re-used (it can also become groundwater) instead of being directed to municipal wastewater. This has a double positive effect, on one hand it reduces the costs of water treatment in sewage treatment plants, on the other it supports the retention of water in the environment.

The authors analyzed the situation in the municipality of Apeldoorn (Fig. 1), because it is characterized by

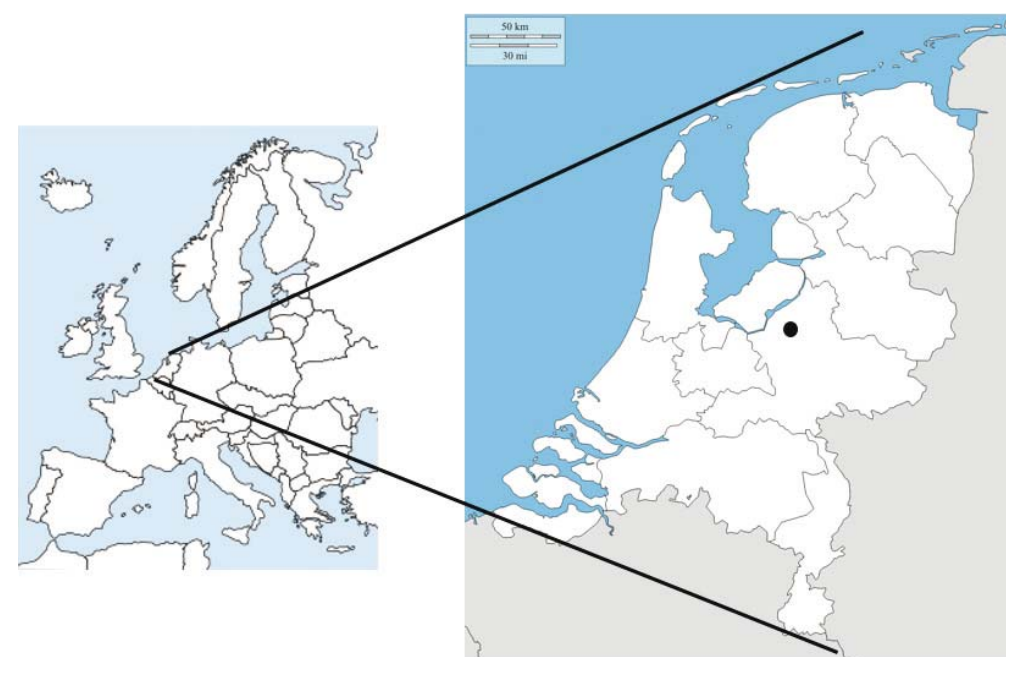

Fig. 1. Selected municipality location 
Boas Berg, A., Jeznach, J., Radziemska, M., Adamcová, D. \& Brtnický, M. (2018). Rain water not in sewers but in the garden - the study case of the Netherlands and Polish experience. Acta Sci. Pol. Architectura, 17 (1), 79-88. doi: 10.22630/ASPA.2018.17.1.8

high intensity and frequency of rainfall. They presented technical solutions that the municipality offers to residents, as well as the possibility of financing investments related to the separation of rainwater from municipal one by the municipality (www.apeldoorn.nl/klimaat).

\section{THE HISTORY OF RAINWATER HARVESTING}

The history of rainwater harvesting can be dated many years back. The archeologists discovered that highly advanced rainwater harvesting systems were created in Jordan around 3000 years B.C. (Jones \& Hunt, 2010). In the Judean desert, that in the south becomes the Negev desert (the territory of the deserts is divided between Israel and the Palestinian Authority), rainwater collecting and storing systems can be found. For example, huge tanks (cisterns) for rainwater, carved in stone, were discovered in the fortress called Masada (Fig. 2). In the Hebrew Bible cisterns are mentioned very often. Palestine was a country with a small amount of precipitation. The accumulation of water had an impact on the functioning and survival of the population (Life Application Study Bible, 2003). In Israel, Palestine and other countries in the Mediterranean region, many cisterns have survived, some of them significant. In addition, there are tank systems under the houses of the Old City of Jerusalem (Fig. 2; Acquistapace, 1992).

On the other hand, in 1960s it was extremely popular in the country regions to use the rainwater for washing (Błażejewski \& Krawczyk, 2008). Nowadays, the situation related to rainwater management in many EU cites is not satisfactory. Cities have ceased to be "spongy" and do not absorb rainwater. The resultant urban flooding causes exceptionally severe damage where massive, rapid urbanization is occurring due to poorly engineered infrastructure (Chen, Samuel- son \& Tong, 2016]. Rainwater very often floods cities that are paved with concrete. This causes a loss of groundwater, which threatens, among other things, urban vegetation. Rainwater flows down the hardened surfaces (Matusiewicz, Koda, Lechowicz \& Osinski, 2016), flushing the pollution and transporting it to rivers and water reservoirs.

Rainfall runoffs do not have enough capacity because they were built in the 19th and early 20th centuries. These outlets were not intended for rainwater accumulating on hardened surfaces such as technical and road infrastructure, supermarket roofs, urban parking lots and other impervious surfaces. A diversification of the most necessary infrastructure facilities availability in individual regions of Poland has been observed for many years (Malinowski, Salamon, Brzychczyk \& Famielec, 2016). Bydgoszcz is one of the Polish cities that have taken care of this problem. The authorities of Bydgoszcz applied for EU subsidies to solve the problem with rainwater (http://bydgoszcz. wyborcza.pl/). In the past, so-called torrential rain was usually about 15-20 minutes long and produced 6-7 mm of rainfall. Today it is on average $30-45 \mathrm{~min}$ utes and produces $16-17 \mathrm{~mm}$ of rainfall. Twice longer the time, twice higher the intensity. The water canals are too small in diameter. The basin has been sealed. It rains more and longer - there is no chance that this outdated system would work. Moreover, it turned out that the sewage system developed in Poland after the war was poorly planned (http://bydgoszcz.wyborcza. $\mathrm{pl} /$ ). The Netherlands is very advanced when it comes to the management of rainwater. Starting in the middle of the 20th century, rainwater is directed here to retention reservoirs which can be water canals, lakes, ponds in the middle of the city, ditches between streets, garden ponds and wadi.
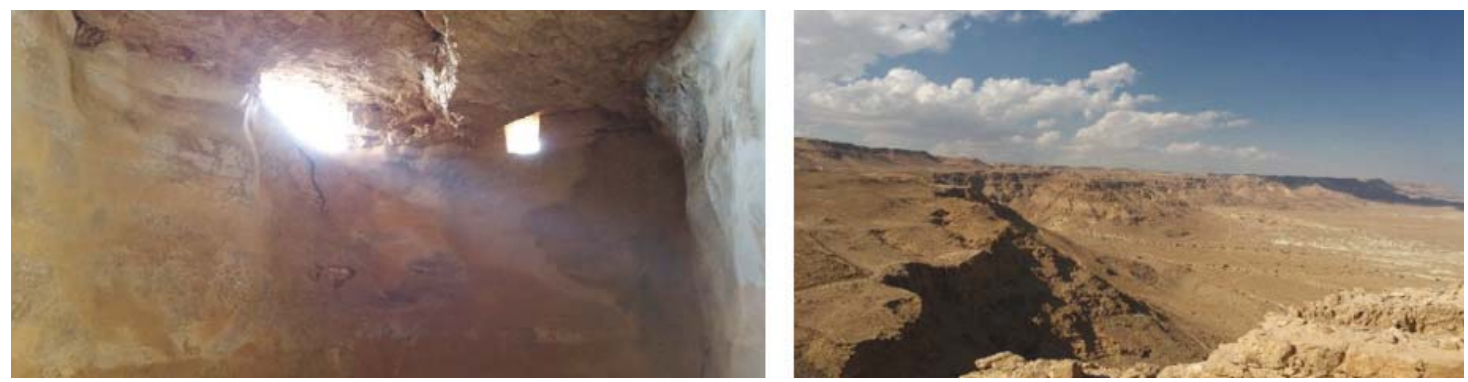

Fig. 2. Rainwater tanks (cisterns), carved in the Masada rock (Boas Berg, Radziemska, Adamcová \& Vaverková, 2017) 
Boas Berg, A., Jeznach, J., Radziemska, M., Adamcová, D. \& Brtnický, M. (2018). Rain water not in sewers but in the garden - the study case of the Netherlands and Polish experience. Acta Sci. Pol. Architectura, 17 (1), 79-88. doi: 10.22630/ASPA.2018.17.1.8

\section{RESULTS AND DISCUSSION}

Apeldoorn is a municipality in the Central Netherlands (Fig. 1) with the largest annual rainfall. Due to climate change rainfall is more rapid than in previous years (www.apeldoorn.nl/klimaat). The municipal sewage system (MSS) transports sewage from households and companies to water treatment plants (WTP). In case of rain, there is also water collected from so-called "hardened surfaces". It is rainwater from roofs, streets and driveways. Municipality of Apeldoorn and the authorities of the WTP 'Vallei en Veluwe' (Fig. 3) are strongly in favor of separating rainwater from the sewage system. By separating rainwater from the MSS (municipality of Apeldoorn offers financial and technical assistance in this area), one can reduce the inconvenience associated with flooding residential areas and local flooding.

In financial terms, it is unreasonable and uneconomical to purify relatively clean water (rainwater). Such situation occurs when rainwater flows down the same runoff as municipal sewage then it enters the municipal WTP. Sewage is diluted with rainwater, which adversely affects their biological purification as well as the amount of water that is undergoes the process of purification. It is a very expensive task for the municipality. Separating rainwater from the municipal water also causes the possibility of preventing drying out of the ground. Also, rainwater feeds the groundwater. The municipality is responsible for separating rainwater from municipal sewage (www.apeldoorn.nl/klimaat) but any individual of the municipality of Apeldoorn can contribute if he or she participates in a project called in The Netherlands 'Operation Stone Break' (www.operatiesteenbreek.nl).

In the case of strong and long-lasting rainfalls, it may happen that the MSS is not able to process all the collected water (municipal sewage and excess rainwater after heavy rainfall). In order to prevent sewage from flowing into the streets, holes are made in the sewage system. Through the hole's excess water is poured into the pond, channel or ditch. Rainwater mixed with municipal sewage (overflowing through openings to a lake or pond) can cause water pollution (fish and bird mortality) and an intense, unpleasant odor disturbing the residents. Another problem associated with rainwater is the load on the capacity of the WTP. Rainwater quickly moves to rainwater channels instead of feeding groundwater's. Stopping rainwater and releasing it into the soil helps to prevent the ecosystem from drying out and further flooding in the lower reaches of the river. Therefore, a better solution is to prevent rainwater from reaching the sewerage through rain pipes. From the area where rainwater gathers, it should go to a wadi (a wadi is obligatorily created in the Netherlands together with the construction of new housing estates). A wadi is a dry valley form in which rainwater collects and infiltrates into the soil (Fig. 4; www.apeldoorn.nl/klimaat). The wadis are constructed with a mixture of sand and humus in the top layer. Underneath the top soil there may be plastic boxes/trenches, storing the water while it infiltrates into the ground. However, according to Koda, Matusiewicz and Osiński (2017) the efficiency of infiltration systems can be disrupted
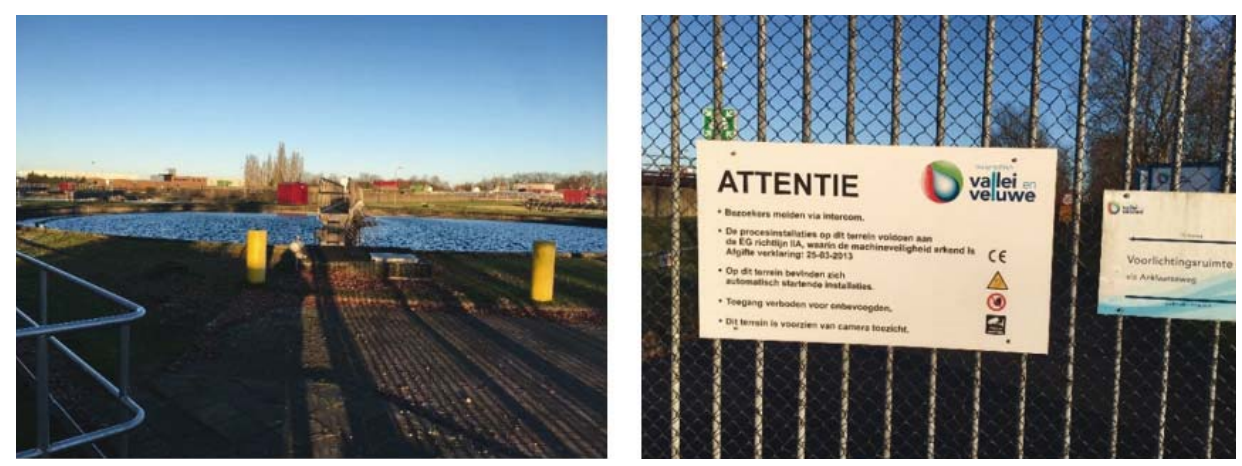

Fig. 3. Water treatment plant in Apeldoorn (Boas Berg et al., 2017) 
Boas Berg, A., Jeznach, J., Radziemska, M., Adamcová, D. \& Brtnický, M. (2018). Rain water not in sewers but in the garden - the study case of the Netherlands and Polish experience. Acta Sci. Pol. Architectura, 17 (1), 79-88. doi: 10.22630/ASPA.2018.17.1.8
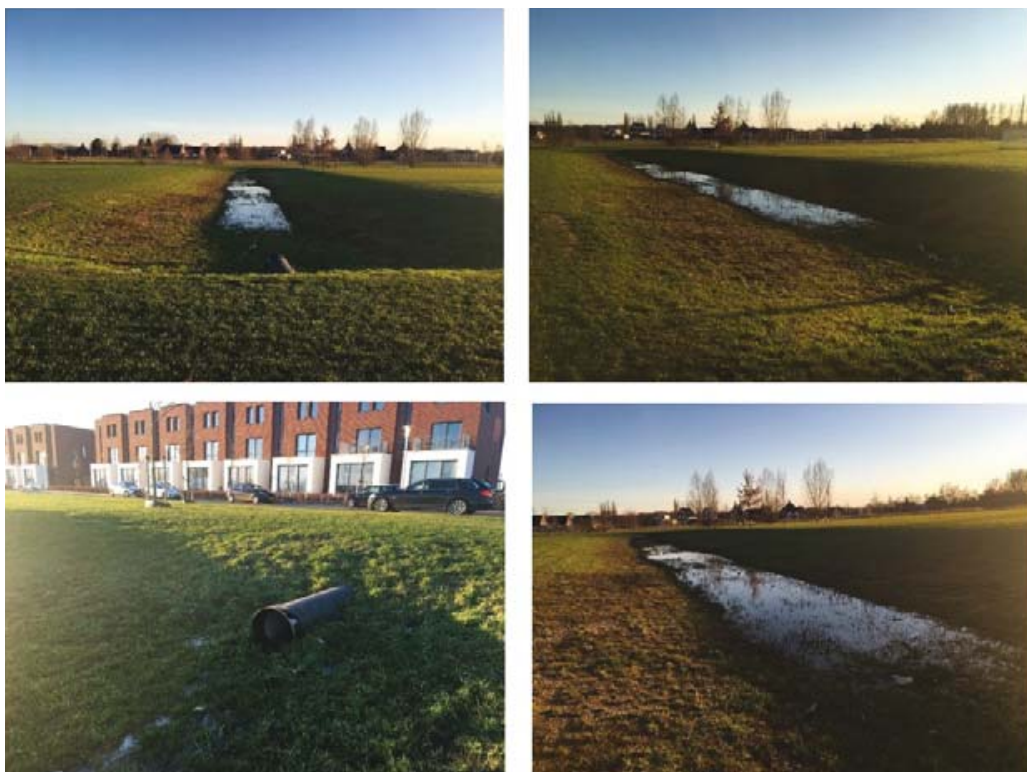

Fig. 4. Pictures of a wadi in a newly built housing estate in the municipality of Apeldoorn (Boas Berg et al., 2017)

due to clogging of infiltration devices, especially when synthetic filters are used.

Rainwater, if it goes to rainwater pipes and municipal sewage, is transported to the WTP and then after purification to the Ijssel River. Rainwater gathered from hardened surfaces may then cause flooding in the lower parts of the Apeldoorn municipality. By stopping as much rainwater in the area where it accumulates and discharging it in a controlled manner (to lakes, canals, tanks with filters under the houses, wadi in the area), we prevent floods in other parts of the area. Rainwater is also collected in the ponds on the east side of the Apeldoorn canal (Fig. 5).
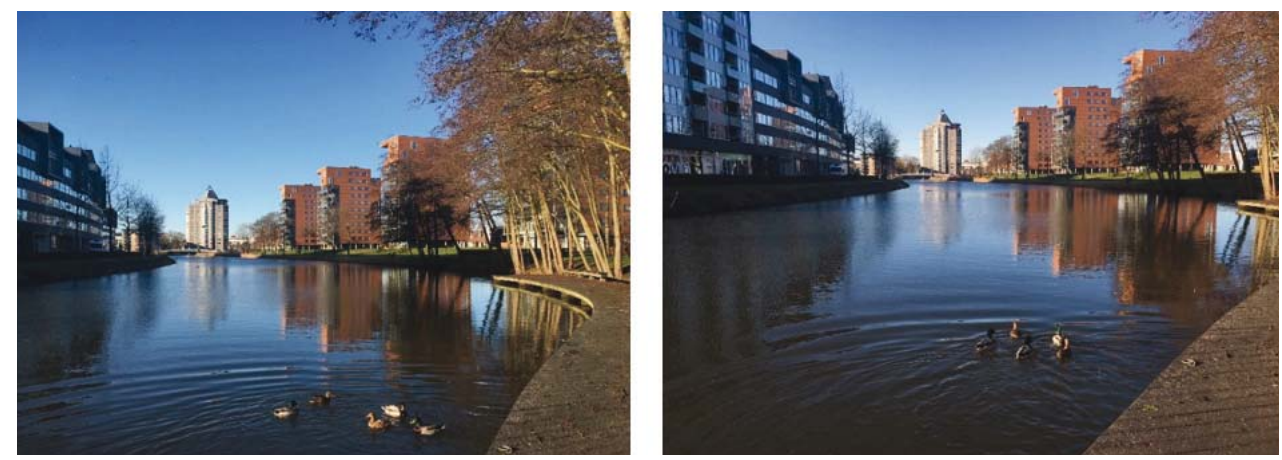

Fig. 5. Apeldoorn canal, a part of the canal located in the city's center (Boas Berg et al., 2017) 
Boas Berg, A., Jeznach, J., Radziemska, M., Adamcová, D. \& Brtnický, M. (2018). Rain water not in sewers but in the garden - the study case of the Netherlands and Polish experience. Acta Sci. Pol. Architectura, 17 (1), 79-88. doi: 10.22630/ASPA.2018.17.1.8
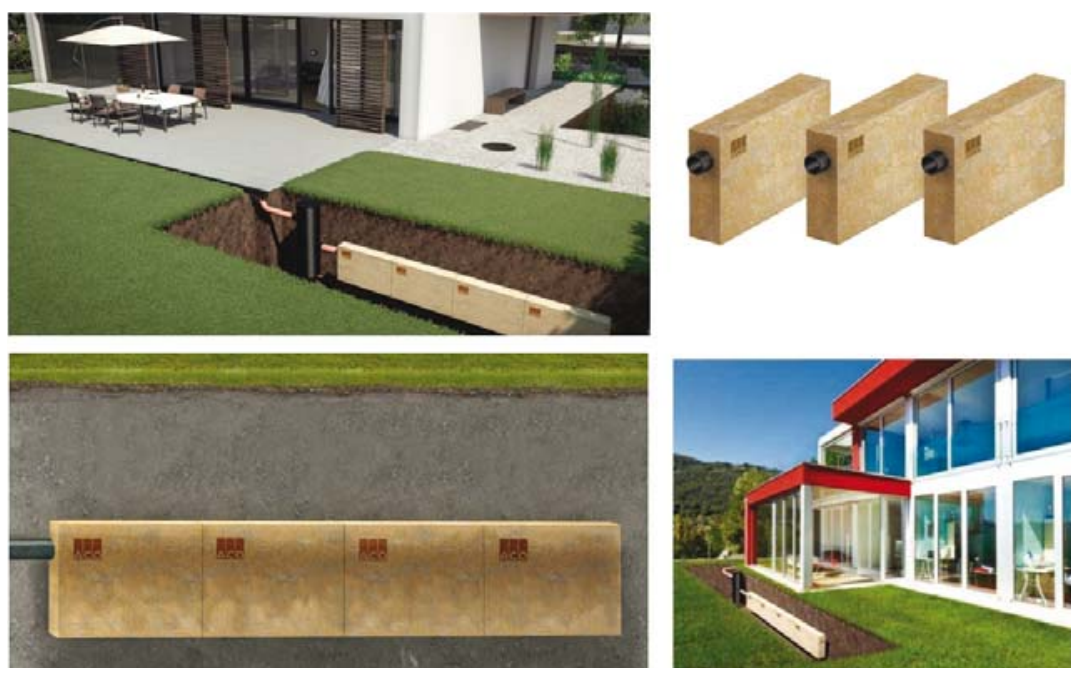

Fig. 6. Infiltration is beneficial for groundwater level, infiltration blocks allow safe flow of rainwater into the garden, photos of underground infiltration system (www.acogarden.be/nl)
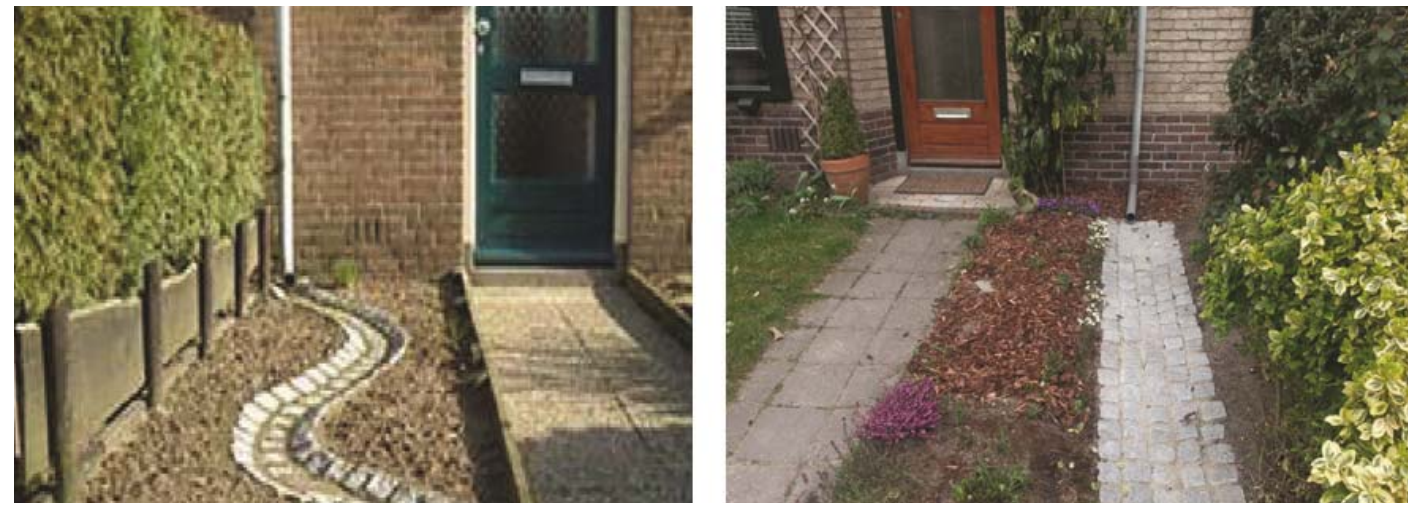

Fig. 7. The pipe is cut off and the water drain is paved so that the surface cannot be washed away (www.apeldoorn.nl/klimaat)

ground outflow (Fig. 7), from which water gets to the holes located on the municipal road. The water flows through the openings to the tank with stone filters and then joins the groundwater. Graywater from houses and blackwater is transported to the municipal sewage and is not mixed with rainwater. Another solution is the wadi mandatorily included in the newly built housing estates, companies and offices structures in the Netherlands. Rainwater is being transported to a wadi. A wadi has a natural permeable bottom. The water penetrates through stone filters and powers groundwater.
Another example of a good solution, collection and use of rainwater is the system installed on the roof of the Sfera II shopping center in Bielsko-Biała (a municipality located in the south of Poland). A housing estate was designed and constructed on the roof of the shopping center. In the inner courtyard of the estate, a garden with an area of about $2,000 \mathrm{~m}^{2}$ was built (Fig. 8). It is an intense garden, with a larger ground cover and with large plants and trees. Trees such as birches, hornbeams and maples and smaller plants such as rose bushes; wild vines and lavender were planted there. The garden surfaces are covered by various gras 

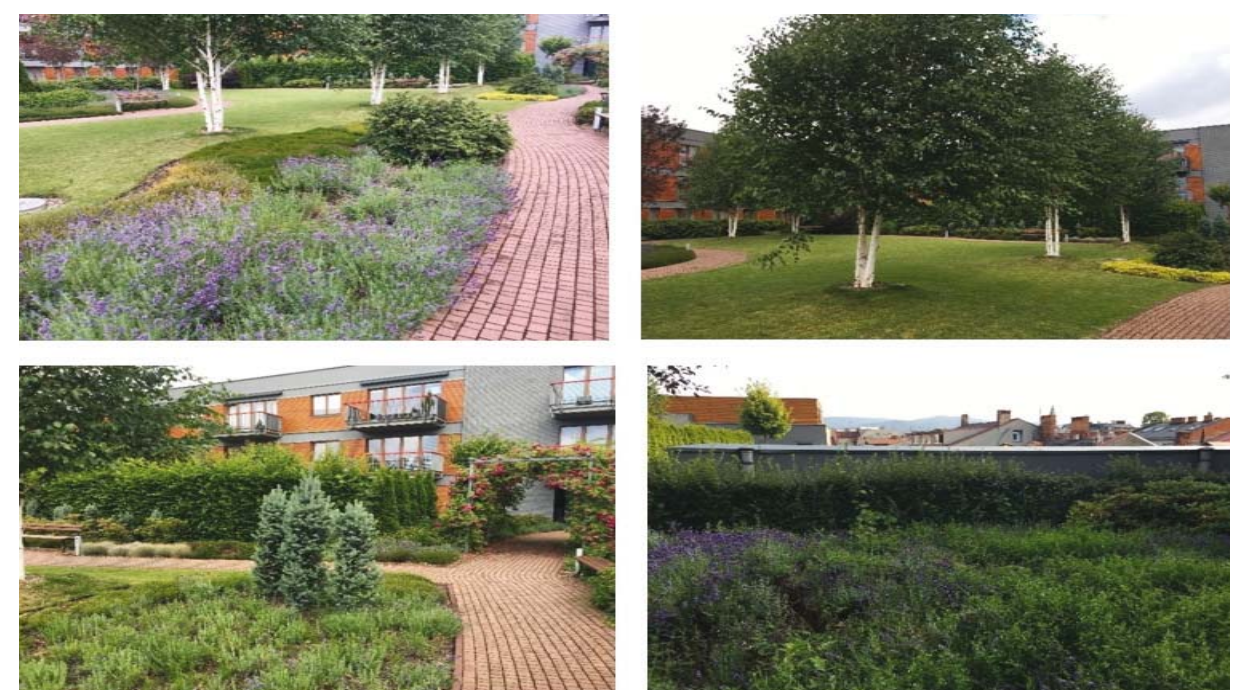

Fig. 8. Garden irrigated by an automatic irrigation system powered by rainwater tanks (Boas Berg et al., 2017)

species. A special irrigation system has also been created - rainwater flows to the tanks (the rainwater drainage system is not connected to a drainage system for municipal sewage). Rainwater from the roof of the Sfera II shopping center is used for watering plants in the garden (Boas Berg at al., 2017).

In Poland professional rainwater management systems are still being developed, but some countries of the EU and the United States of America (USA) are very advanced in this matter. For example, in Belgium, there is an obligation to have a rainwater collection system in newly built buildings with a roof area above $100 \mathrm{~m}^{2}$ (Domenach \& Saurí, 2011). In the Netherlands, municipalities have introduced a system that informs and educates the local community about water saving possibilities and thus the household budget. In addition, the municipality will prepare a project for a given house and finance the construction of the installation enabling the use of rainwater instead of discharging it to municipal sewage (www. apeldoorn.nl/klimaat). In the USA, such an obligation was imposed on new buildings in Tucson (Arizona) and Santa Fe County (New Mexico). In southern Australia, all houses have access to alternative sources of water (including rainwater systems, among others). In addition, there are places where investments in rainwater management were supported, among others through tax exemptions, i.e. in San Antonio,
Texas (Domenach \& Saurí, 2011). Along with the development of urban planning and construction of concrete housing estates, hardened and paved markets and squares in cities, streets and parking lots, people started treating rainwater (rainwater as well as snowfall etc.) as a threat, forgetting that these are important water resources to use. The constructors of residential houses, office buildings, buildings intended for production purposes tried to avoid excess rainwater around their buildings. Basically, only one approach to rainwater management has been used: to discharge it to the receivers as quickly as possible. This situation, however, has the opposite effect. When there is a heavy rainfall, sewage systems are overloaded. It causes flooding in the lower areas of the municipality. Simultaneously, in the region where rainwater should remain in the ecosystem, there is a groundwater shortage.

Increasing areas with sealed surfaces (concreted squares, streets, areas around residential buildings) as well as increasing demand for water (e.g. due to industrial development), as well as climatic changes affecting rainfall distributions cause a situation in which rainwater collection or separation its use in municipal sewage will be an obligatory activity in the future.

The first actions concerning the increase in fees for improper management of rainwater were taken 

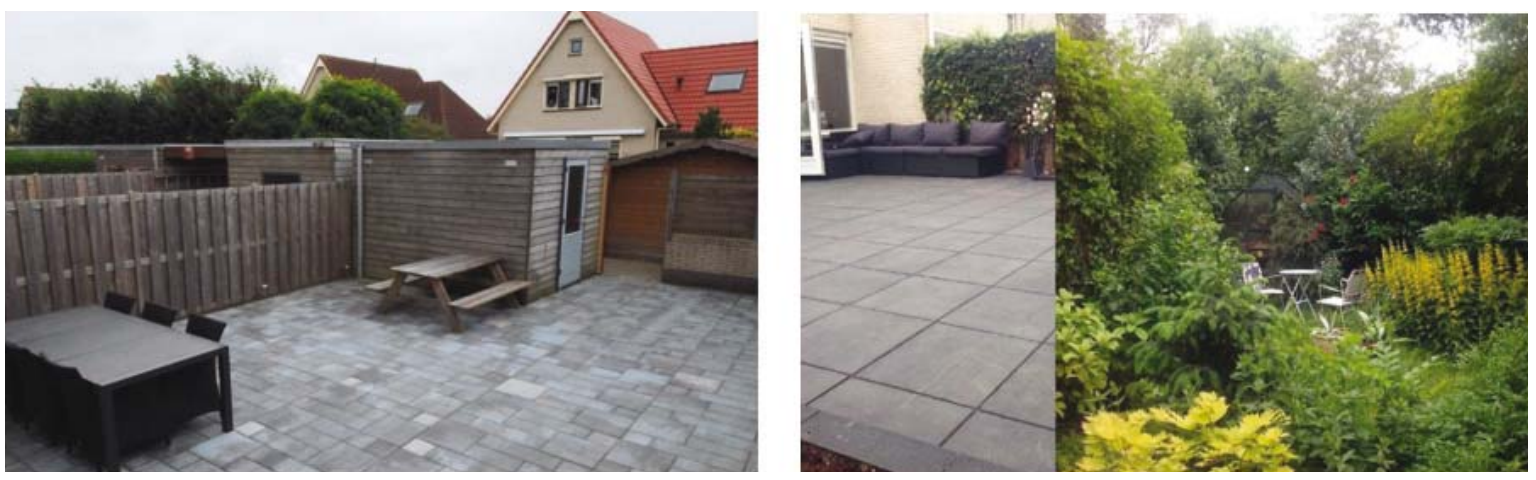

Fig. 9. Pictures of the concrete garden of the municipality of Altena (www.gemeente.nu)

by the Dutch municipality of Altena (North Brabantia province). From January 1, 2018, the municipality will charge a higher tax on sewage if the owner paves his garden. The tax on the paved garden will be collected from the property owner because the tiles cause too much pressure on the sewage system, which leads to flooding. In the green garden, the water is better absorbed in the ground. Thanks to this plan, the municipality wants to make citizens aware of problems with draining water and encourage them to install grass in the garden instead of hardening the surface (Fig. 9; www.gemeente.nu).

\section{CONCLUSIONS}

In European cities, as well as in Polish, there is a lot of hardened areas like parking lots, city infrastructure, pavements, pitches made of concrete tiles, roofs of large supermarkets, etc. These types of land cause rainwater being not absorbed into the ground. The water only moves on the surface, causing flooding in the areas located lower. If rainwater is not able to be absorbed in the area where it occurred (i.e. in the area where rainfall occurs), it may cause a loss of groundwater, which threatens, among other things, urban vegetation. Rainwater flows down the paved surfaces, flushing pollution and transporting it to rivers and water reservoirs. Rainfall runoffs in European municipalities do not have sufficient capacity because they were not intended for rainwater that accumulates in significant quantities (currently, the number of hard- ened and impermeable surfaces has been increased). Stopping rainwater and letting it into the soil helps to prevent the ecosystem from drying out and flooding in areas located lower. Therefore, the best solution is to prevent rainwater from reaching the sewage system through rain pipes. In the Dutch municipalities, the municipal authorities offer several solutions. When new housing estates and houses are being built, then an obligatory wadi is created with a housing estate (wadi has been described earlier in the article). In old way of construction, however, the rain gutter can be disconnected from the sewage system and rainwater flows to wadi, (which is created in the area). Dutch municipalities offer subsidizing investments to encourage residents to these changes.

\section{REFERENCES}

ACO Garden: Infiltration Line (online). 30.01 .2018 (cit. 2018-01-30). Available from: http://acogarden.be/nl/ product/infiltration-line

Acquistapace, P. (1992). Guida biblica e turistica della Terra Santa. Milano: Istituto Propaganda Libraria.

Apeldoorn: Klimaat (online). 30.01.2018 (cit. 2018-01-30). Available from: https://www.apeldoorn.nl/klimaat

Bellard, C., Bertelsmeier, C., Leadley, P., Thuiller, W. \& Courchamp, F. (2012). Impacts of climate change on the future of biodiversity. Ecology Letters, 15, 365-377.

Błażejewski, R. \& Krawczyk, J. (2008). Zaopatrzenie w wodę i kanalizacja wsi w Wielkopolsce w XX wieku. Rocznik Muzeum Narodowego Rolnictwa i Przemystu Rolno-Spożywczego w Szreniawie, 25, 407. 
Boas Berg, A., Jeznach, J., Radziemska, M., Adamcová, D. \& Brtnický, M. (2018). Rain water not in sewers but in the garden - the study case of the Netherlands and Polish experience. Acta Sci. Pol. Architectura, 17 (1), 79-88. doi: 10.22630/ASPA.2018.17.1.8

Boas Berg, A., Radziemska, M., Adamcová, D. \& Vaverková, M. D. (2017). Green roofs as an alternative solution to reduced Green surface area in highly urbanized cities of the European Union - the study case of the Netherlands. Acta Scientiarum Polonorum Architectura, $16(4), 59-70$.

Chen, Y., Samuelson, H. W. \& Tong, Z. (2016). Integrated design workflow and a new tool for urban rainwater management. Journal of Environmental Management, $180,45-51$.

De Roeck, F., Orbie, J. \& Delputte, S. (2018). Mainstreaming climate change adaptation into the European Union's development assistance. Environmental Science \& Policy, 81, 36-45.

Ding, H., Chiabai, A., Silvestri, S. \& Nunes, P.A.L.D. (2016). Valuing climate change impacts on European forest ecosystems. Ecosystem Services, 18, 141-153.

Domenach, L. \& Saurí, D. (2011). A comparative appraisal of the use of rainwater harvesting in single and multifamily buildings of the Metropolitan Area of Barcelona (Spain): social experience, rinking water savings and economic costs. Journal of Cleaner Production, 6-7, 598-608.

Foden, W. B., Butchart, S. H. B., Stuart, S. N., Vié, J.-C., Akçakaya, H. R., Angulo, A. \& Mace, G. M. (2013). Identifying the world's most climate change vulnerable species: A systematic trait-based assessment of all birds, amphibians and corals. PLoS One, 8, 65427.

Francés, G. E., Quevauviller, P., González, E. S. M. \& Amelin, E.V. (2017). Climate change policy nd water resources in the EU and Spain. A closer look into the Water Framework Directive. Environmental Science \& Policy, 69, 1-12.

Gardali, T., Seavy, N. E., DiGaudio, R. T. \& Comrack, L. A. (2012). A climate change vulnerability assessment of California's at-risk birds. PLoS One, 29507.

Gemeente.nu: Deze pagina is niet gevonden (online). 30.01.2018 (cit. 2018-01-30). Available from: https:/ www.gemeente.nu/ruimte-milieu/minder-groen-tuinbetekent-meer-belasting

Jones, P. M. \& Hunt, F. W. (2010). Performance of rainwater harvesting systems in the southeastern United States. Resources, Conservation and Recycling, 54 (10), 623-629.

Koda, E., Matusiewicz, W. \& Osiński, P. (2017). Niesprawność systemów odwadniających w obiektach budowlanych. W XXVIII Konferencja Naukowo-Techniczna „Awarie budowlane”, strony 411-422, Międzyzdroje.

Life Application Study Bible (2003). Wheaton Illinois, Tyndale House Publishers.

Maione, M., Fowler, D., Monks, P. S., Reis, S., Rudich, Y., Williams, M. L. \& Fuzzi, S. (2016) Air quality and climate change: Designing new win-win policies for Europe. Environmental Science \& Policy, 65, 48-57.

Malinowski, M., Salamon, J., Brzychczyk, B.\& Famielec, S. (2016). Assessment of water supply and wastewater infrastructure development dynamics in Poland in the years 2003-2013. Infrastructure and ecology of rural areas, 1911-1922.

Matusiewicz, W., Koda, E., Lechowicz, Z. \& Osinski, P. (2016). Assessment of the flooding cause of the structure located near the reservoir retaining rainwater from dewatering of a motorway. Available from: http://www. materialybudowlane.info.pl/381-wydanie/mb-201612/10014-ocena-przyczyn-podtopienia-obiektu-w-rejonie-zbiornika-retencyjnego-wod-opadowych-z-odwodnienia-drogi-szybkiego-ruchu.html

Petrović, N., Bojović, N. \& Petrović, J. (2016). Appraisal of urbanization and traffic on environmental quality. Journal of $\mathrm{CO}_{2}$ Utilization, 16, 428-430.

Samen voor meer groen in de buurt! (online). 30.01.2018 (cit. 2018-01-30). Available from: https://www.citacepro.com/dokument/tJGyQtjj5CFYZsmz

Stahn, H. \& Tomini, A. (2017). On conjunctive management of groundwater and rainwater. Resource and Energy Economics, 49, 186-200.

Thomas, C. D., Gillingham, P. K., Bradbury, R. B., Roy, D. B., Anderson, B. J., Baxter J. M. \& Hill, J. K. (2012). Protected areas facilitate species' range xpansions. Proceedings of the National Academy of Sciences of the USA, 109, 14063-14068.

Warren, R., Van Der Wal, J., Price, J., Welbergen, J. A., Atkinson, I., Ramirez-Villegas, J. \& Lowe, J. (2013). Quantifying the benefit of early climate change mitigation in avoiding biodiversity loss. Nature Climate Change, 3, 678-682.

Wyborcza.pl: Deszczówka to wrzód (online). 30.01.2018 (cit. 2018-01-30). Available from: http://bydgoszcz.wyborcza.pl/bydgoszcz/7,48722,21983774,deszczowkato-wrzod-dlaczego-wciaz zalewa-polskie-miasta.html 


\section{DESZCZOWA WODA NIE W KANALIZACJI A W OGRODZIE - PRZYKŁADY ROZWIAZZAŃ Z HOLANDII I POLSKI}

\section{STRESZCZENIE}

Artykuł zawiera informacje na temat możliwości oddzielania wody deszczowej od ścieków komunalnych oraz jej ponownego wykorzystania. Rozważania oparto na doświadczeniach gmin w Unii Europejskiej, w szczególności na gminie holenderskiej. Wybór holenderskiej gminy Apeldoorn nie był przypadkowy. Odnotowuje się tu najwyższy poziom opadów w całej Holandii. Holandia jest jednym z tych europejskich państw, które bardzo dobrze gospodarują zasobami wodnymi. Wynika to z faktu, że jest to kraj mały, o gęstym zaludnieniu, rozprowadzający zasoby wodne w bardzo zaludnionych gminach. Ponadto $50 \%$ tego kraju leży poniżej poziomu morza, co powoduje także problemy z nadmiarem wody w prowincjach nadmorskich. Holendrzy mają doświadczenie z wielkimi katastrofami wodnymi, np. kiedy w latach 50. XX wieku, morze wtargnęło w głąb lądu, zabijając prawie 2000 osób. Starają się zatem gospodarować wodą z wykorzystaniem wszelkich możliwości technicznych i prawnych. W artykule zaprezentowano niektóre sposoby oddzielania wody deszczowej od ścieków komunalnych na terenie gminy Apeldoorn oraz subsydia przeznaczone na ten cel. Przedstawiono także krótką historię wykorzystywania wody deszczowej, nie omijając polskich doświadczeń. W tym jeden ze sposobów wykorzystywania deszczówki w polskim mieście Bielsko-Biała, które ma zbliżoną liczbę mieszkańców jak gmina Apeldoorn oraz relatywnie wysokie opady.

Słowa kluczowe: woda deszczowa, oddzielenie wód opadowych, dotacje unijne, suche koryto, wody gruntowe 